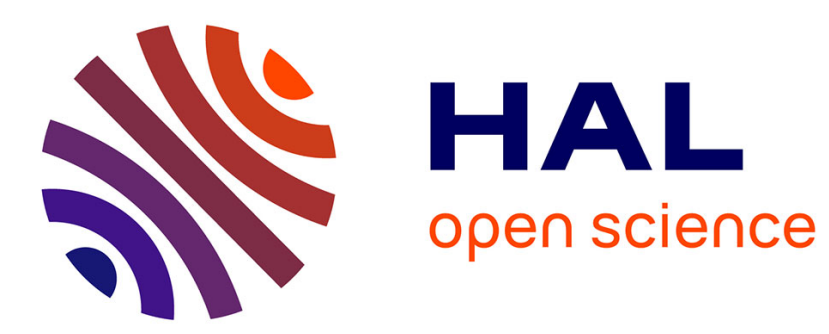

\title{
Evaluation of colony losses in Israel in relation to the incidence of pathogens and pests
}

Victoria Soroker, Amots Hetzroni, Boris Yakobson, Dan David, Alina David, Hilary Voet, Yossi Slabezki, Haim Efrat, Shlomit Levski, Yossi Kamer, et al.

\section{- To cite this version:}

Victoria Soroker, Amots Hetzroni, Boris Yakobson, Dan David, Alina David, et al.. Evaluation of colony losses in Israel in relation to the incidence of pathogens and pests. Apidologie, 2011, 42 (2), pp.192-199. 10.1051/apido/2010047 . hal-01003581

\section{HAL Id: hal-01003581 \\ https://hal.science/hal-01003581}

Submitted on 1 Jan 2011

HAL is a multi-disciplinary open access archive for the deposit and dissemination of scientific research documents, whether they are published or not. The documents may come from teaching and research institutions in France or abroad, or from public or private research centers.
L'archive ouverte pluridisciplinaire HAL, est destinée au dépôt et à la diffusion de documents scientifiques de niveau recherche, publiés ou non, émanant des établissements d'enseignement et de recherche français ou étrangers, des laboratoires publics ou privés. 


\title{
Evaluation of colony losses in Israel in relation to the incidence of pathogens and pests*
}

\author{
Victoria SOROKER ${ }^{1}$, Amots HeTZRONI $^{2}$, Boris YAKOBSON ${ }^{3}$, Dan DAVID ${ }^{3}$, Alina \\ DAVID $^{3}$, Hilary VoET ${ }^{4}$, Yossi SLABEZKI ${ }^{5}$, Haim EFRAT ${ }^{5}$, Shlomit LEVSKI $^{1}$, Yossi \\ KAMER $^{1}$, Etta KLINBERG ${ }^{1}$, Naama ZIONI ${ }^{1}$, Shani INBAR ${ }^{1}$, Nor CHEJANOVSKY ${ }^{1}$ \\ ${ }^{1}$ Department of Entomology, Institute of Plant Protection, Agricultural Research Organization, \\ The Volcani Center, POB 6 Bet Dagan, 50250, Israel \\ ${ }^{2}$ Department of Sensing, Information and Mechanization Engineering, Agricultural Research Organization, \\ the Volcani Center, 50250 POB 6 Bet Dagan, Israel \\ ${ }^{3}$ The Kimron Veterinary Institute, Israel \\ ${ }^{4}$ Faculty of Agriculture, Food and Environment The Hebrew University of Jerusalem, POB 12 Rehovot 76100, \\ Israel \\ ${ }^{5}$ Extension Service Ministry of Agriculture, Israel
}

Received 7 October 2009 - Revised 11 March 2010 - Accepted 29 March 2010

\begin{abstract}
To evaluate symptoms, extent, and possible causes of colony decline and losses in Israel, we carried out (1) a survey of honeybee colony losses and potential causes via mail and phone; (2) systematic sampling of healthy and problematic beehives after requeening in the winter; (3) detection of Varroa and pathogens including, viruses and Nosema ceranae, by microbiological means and sensitive RT-PCR. From 58 beekeepers ( 46000 colonies) interviewed, $40 \%$ complained of extensive colony loses during 2008 . Examination and sampling for pests and pathogens of 113 hives in the winter of 2009 showed $35 \%$ of hives with Nosema and $21 \%$ with $V$. destructor. The most frequent viruses detected were Black Queen Cell Virus, Israeli Acute Paralysis Virus, and Deformed Wing Virus. A significant negative correlation was found between worker population in the hive and the presence of viral and Nosema infections.
\end{abstract}

Apis mellifera / Bee viruses / Varroa / Nosema

\section{INTRODUCTION}

During the last two years, reports of heavy colony losses worldwide have raised public concern and awareness for the future of honeybees. Due to the high ecological and economic significance of bees in general and honey bees in particular, scientists in many countries have been joining efforts to quantify the incidence and causes of honeybee loses (CoxFoster et al., 2007; COLOSS, 2009; Giray et al., 2010; EFSA, 2008).

Israel has one of the highest beekeeping densities in the world, with 100000 hives

Corresponding author: V. Soroker, sorokerv@ volcani.agri.gov.il

* Manuscript editor: David Tarpy per $7000 \mathrm{~km}^{2}$, since most of the country area is too arid and unsuitable for apiculture. These hives are maintained by approximately 450 beekeepers producing 3200 metric tons of honey (a value of 12 million USD) and 100000 cycles of pollination services to different crops (an augmented income of 250 million USD). Commonly cultivated bee stocks in Israel are Apis mellifera ligustica, Apis mellifera caucasica, and Buckfast, in addition to the local native bees of Apis mellifera syriaca. Until approximately 25 years ago, the hilly and mountainous regions of the country were populated with colonies of strong and healthy feral bees. However, this population was recently extinguished, probably due to the appearance of Varroa destructor. 
V. destructor is of particular concern and is considered to be the most threatening factor in the survival of the honeybee population (Navajas et al., 2010; Giray et al., 2010; EFSA, 2008; Guzmán-Novoa et al., 2010). It was first detected in Israel in 1984, and its reproduction was accelerated under the local warm climatic conditions and constant availability of honey bee brood. High hive density and mobility have also contributed to spread of the Varroa, and the first deaths of colonies due to heavy mite infestations were observed by 1985 (Efrat and Slabezki, unpubl. data). Current mite control is achieved by applying coumaphos-impregnated Checkmite $+{ }^{\circledR}$ strips.

Beside $V$. destructor, bees in Israel suffer from Acarapis woodi and a variety of pathogens, including Nosema and viruses (Efrat and Slabezki, 2007). In parallel to reports of dramatic colony losses of up to $35 \%$ in the US (van Engelsdorp et al., 2008, 2009), Israeli commercial beekeepers have estimated an annual loss of $25 \%$. Moreover, their colonies have not been as strong as previous years and honey crop yield has been reduced. Aiming to find the possible causes for the decline of local colonies, a comprehensive study of the incidence and characteristics of colony losses in Israel was initiated. Our goals were to evaluate (a) the extent and symptoms of colony decline and losses, country wide; and (b) the role of pathogens and parasites on colony health.

This report presents the findings of survey and extensive, wide sampling after requeening in the winter of 2009.

\section{MATERIALS AND METHODS}

\subsection{Beekeepers survey}

A survey of honeybee colony losses and the potential causes was conducted by a questionnaire distributed via mail and fax among 100 registered growers representing the majority of bee colonies and all sizes of bee operations in the country. The questionnaire was divided into eight sections: (1) general information on farm size, region of activity, and habitat; (2) breeding stock; (3) management visits and protocols; (4) general problems recorded in apiary; (5) disease management protocols; (6) timing of treatments; (7) swarm management; and (8) estimates of apiary loss (see supplementary material for a complete survey form).

\subsection{Direct hive examination and bee sampling}

Systematic sampling of beehives after requeening in January 2009 was performed at 12 selected sites throughout the country. Ten colonies were sampled in each site, except for one site where only three hives were assessed.

The assessment procedure included: (1) estimation of colony population size by counting the number of inhabited frames (adult population size) and evaluating the capped brood area in decimeters (brood population size); (2) recording the health of the adult bees and brood; (3) evaluation of the Varroa population by counting the number of mites found on a sticky board at the hive bottom, following one hour of Amitraz fumigation (Herbert et al., 1989); and (4) collection of 50 adult bees from honey combs from each hive for pathogen examination (see below).

\subsection{Pathogen and pest examination and diagnostics}

Pathogens such as Nosema sp. and viruses were identified using RT-PCR. Briefly, for viral detection, total RNA was extracted from brood and adult frozen bees with Tri-reagent (Molecular Research Center) according to the manufacturer's protocol and resuspended in RNase- and DNase-free water. Reverse transcription was performed using Masterscript reverse transcriptase (5-Prime $\mathrm{GmbH}$ ). PCR of the obtained cDNA was performed using the following protocol: $95{ }^{\circ} \mathrm{C}$ for $5 \mathrm{~min}, 40$ cycles of $95{ }^{\circ} \mathrm{C}$ for $30 \mathrm{~s}, 55{ }^{\circ} \mathrm{C}$ for $30 \mathrm{~s}, 72{ }^{\circ} \mathrm{C}$ for $1 \mathrm{~min}$, and a final amplification step of $72{ }^{\circ} \mathrm{C}$ for 10 min utilizing primers specific for acute bee paralysis virus (ABPV), black queen cell virus (BQCV), chronic bee paralysis virus (CBPV), deformed wing virus (DWV), Israeli acute paralysis virus (IAPV), Kashmir bee virus (KBV), sacbrood virus (SBV), and Varroa destructor virus-1 (VaDV-1) (Blanchard et al., 2007; Benjeddou et al., 2001; Berényi et al., 2006; Chen et al., 2005; Maori et al., 2007; Ongus et al., 2004; Stolz et al., 1995; see supplementary material Tab. I). Selected PCR products were sequenced for further confirmation of the viral products. 
Nosema analysis was conducted according to Martin-Hernández et al. (2007). Prior to PCR, 20 adult honey bees from each sample were macerated in $20 \mathrm{~mL}$ distilled water and an aliquot was examined under Microscope at 400X. The suspension of Nosema-positive samples was filtered and centrifuged at $2500 \mathrm{rpm}$ for $15 \mathrm{~min}$. For DNA extraction, spore germination was induced with $500 \mu \mathrm{L}$ germination buffer $(0.5 \mathrm{M}$ sodium chloride, $0.5 \mathrm{M}$ sodium hydrogen carbonate, $\mathrm{pH} 6.0$ adjusted with ortophosphoric acid), and the mixture was incubated at $37^{\circ} \mathrm{C}$ for $15 \mathrm{~min}$. The samples were centrifuged at $2500 \mathrm{rpm}$ for $10 \mathrm{~min}$ and $200 \mu \mathrm{L}$ of the supernatant were subjected to DNA extraction using DNeasy Blood and Tissue kit (Qiagen) after centrifugation at $2500 \mathrm{rpm}$ for $10 \mathrm{~min}$.

Both microsporidia N. apis and N. ceranae were distinguished using species-specific primers (supplementary material, Tab. II). Multiplex PCR reactions were performed with Taq DNA polymerase (AmpliTaq, Perkin-Elmer). The PCR profile included denaturing the DNA at $95{ }^{\circ} \mathrm{C}$ for $10 \mathrm{~min}$ followed by 39 cycles at $94{ }^{\circ} \mathrm{C}$ for $30 \mathrm{~s}, 50{ }^{\circ} \mathrm{C}$ for $30 \mathrm{~s}$, and $72{ }^{\circ} \mathrm{C}$ for $2 \mathrm{~min}$, followed by final step of $72{ }^{\circ} \mathrm{C}$ for $10 \mathrm{~min}$. Negative controls (from DNA extraction) were included in all PCR experiments. The PCR products were evaluated by agarose electrophoresis stained with ethidium bromide and viewed by UV illumination.

\subsection{Data analysis}

For survey analysis, we defined colony losses as "severe" when they were above $20 \%$ for a given operation. Statistical analysis was performed using SAS 9.1. Association between continuous variables was expressed by the Pearson correlation coefficient $(r)$ and association between pairs of ordinal variables or ordinal variables with continuous variables was expressed by the Kendall's Tau-b correlation coefficient. Multiple linear regression was used to examine simultaneously the effect of different pathogens on bee population size. The marginal significance of each virus within this model was determined by t-test.

\section{RESULTS}

Questionnaires were collected from 58 beekeepers for 2008. Although these growers constitute only $13 \%$ of total number of beekeepers, the collected data represent about

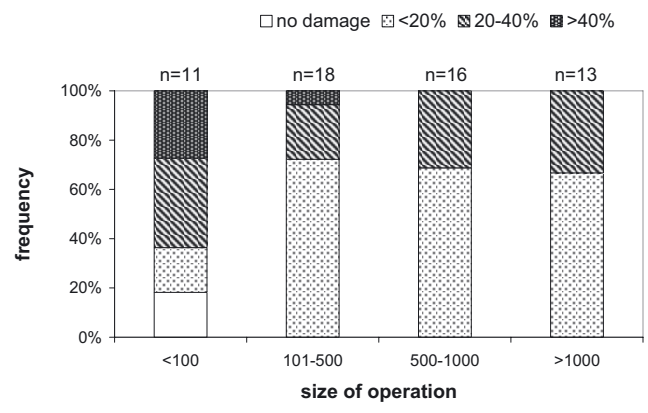

Figure 1. Distribution of losses levels among the responding beekeepers divided according the size of their operation. Number on the bar indicates total responding beekeepers in each category.

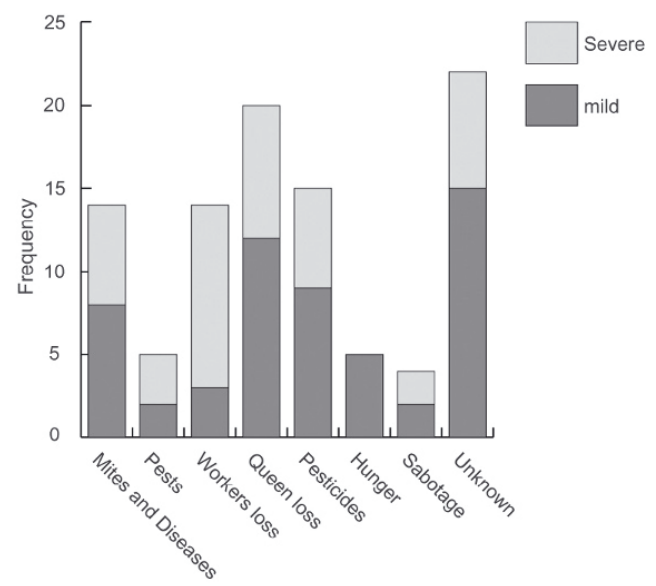

Figure 2. Potential causes as reported by the beekeepers. Distribution between two levels of damage mild and severe (up to and above $20 \%$, respectively).

46000 colonies (almost 50\%) since most of the replying beekeepers owned large operations (more than 1000 colonies). The level of losses varied widely among the operation (Fig. 1), some of which reached above $40 \%$ but losses occurred mainly in small operations (up to 100 colonies).

Some of the beekeepers observed CCDlike symptoms (collapsed colony with a living queen surrounded by a small group of young workers), while others reported queen loss. However, most of the losses were reported as unknown and could have resulted from multiple factors, including pests, diseases, or pesticides (Fig. 2). 

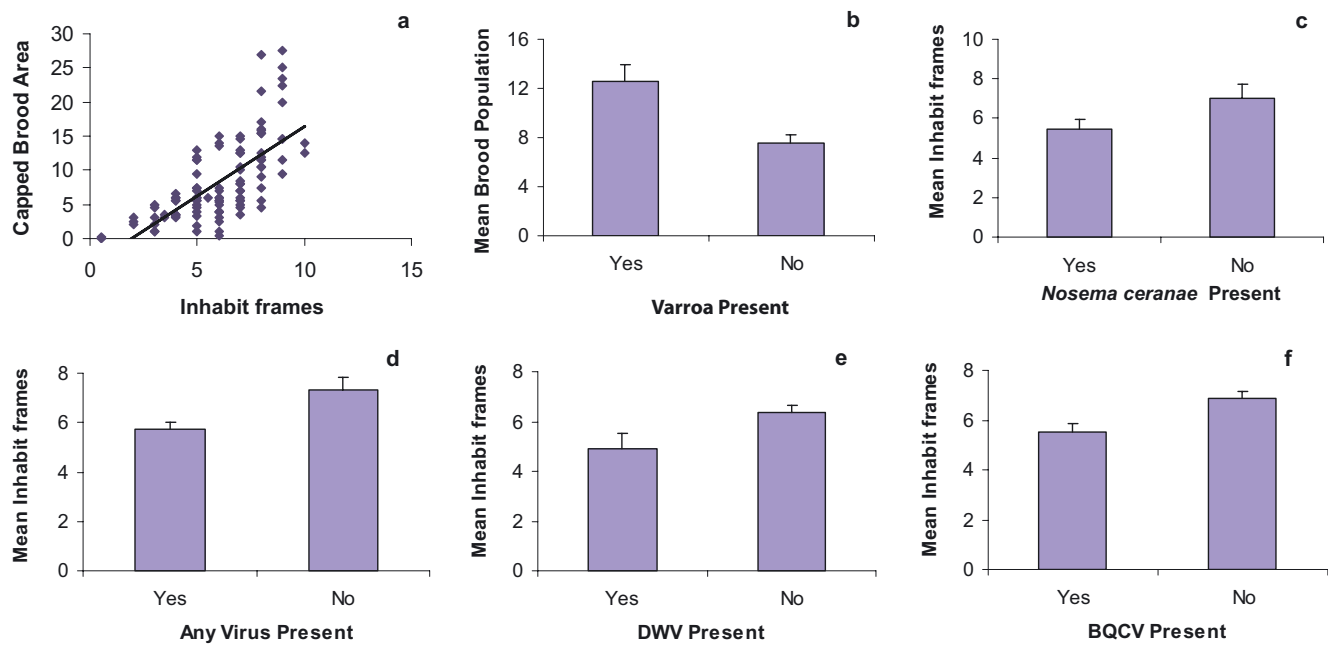

Figure 3. Correlation between adult population estimate (inhabit frames) and capped brood area in decimeters (a); association between pests and pathogens and the colony population (b-f).

Of the 113 hives directly examined in January, only one colony showed CCD-like symptoms. Others appeared healthy initially, but nine colonies collapsed by July.

Within the examined hives, bees inhabited $5.97 \pm 0.21($ mean \pm SE) frames and the area of capped brood was $8.5 \pm 0.58$ (mean \pm SE) decimeters. A significant positive correlation was found between the estimates of adult and brood population size $(\mathrm{r}=0.68, \mathrm{n}=103, P<$ 0.0001; Fig. 3a). From the 113 hives that were directly examined and sampled for pests and pathogens, microscopic examination revealed Nosema in $35 \%$. Subsequent PCR confirmed infestation in $77 \%$ of the Nosema-positive cases, all of which were $N$. ceranae. A significant negative correlation was found between the infestation with $N$. ceranae and adult (but not brood) population (tau-b $=-0.32, \mathrm{n}=32$, $P=0.03$ and tau-b $=-0.11, \mathrm{n}=32, P=0.44$ respectively; Fig. 3c).

$V$. destructor was detected in $21 \%$ of the hives. Despite the high percentage of colonies with Varroa, the number of mites detected per colony was very low $(0.9 \pm 0.30$; mean \pm SE $)$. The incidence of Varroa showed a low, but significant positive correlation with brood population (tau-b $=0.28, \mathrm{n}=106, P<0.001$; Fig. 3b), but not adult bee population (tau$\mathrm{b}=0.11, \mathrm{n}=101, P=0.19)$. There was no correlation between the incidence of Varroa and that of $N$. ceranae (tau-b $=-0.16, \mathrm{n}=29$, $P=0.38)$. Acarapis woodi was not detected in the weak colonies tested.

Analysis for the incidence of viruses in 71 representative colonies revealed the presence of ABPV, BQCV, CBPV, DWV, IAPV, SBV, and VaDV-1 (Tab. I). BQCV, IAPV, DWV, and VaDV-1 were detected most frequently, in decreasing order (see Tab. I). KBV and CBPV were not detected. In $42 \%$ of the tested hives, workers were infected by more than one virus. Honey bee viruses were detected at all tested sites (Fig. 4), with more than one virus type per site. However, no evident clinical signs of viral infections were detected in most cases. Still, a significant negative correlation (tau-b $=-0.24, \mathrm{n}=68, P<0.05$ ) was found between the population of adult workers in the hive and the incidence of viral infection (Fig. 3d). Correlation between the capped brood area and the incidence of viral infection was lower and not statistically significant (tau-b $=-0.14, \mathrm{n}=68, P=0.18$ ). Both BQCV and DWV were significantly negatively correlated with the population of adult workers (tau-b $=-0.25, \mathrm{n}=68, P<0.05$; and tau-b $=-0.22, \mathrm{n}=68, P<0.05$, respectively; Fig. 3e and f). The correlation between the latter and the capped brood area was 
Table I. Viral incidence.

\begin{tabular}{lc}
\hline Viruses tested & $\begin{array}{r}\text { Relative frequency of detected viruses* } \\
\text { \% of hives tested }(\mathrm{n}=71)\end{array}$ \\
\hline Black queen cell virus (BQCV) & 62 \\
Israeli acute paralysis virus (IAPV) & 35 \\
Deformed wing virus (DWV) & 23 \\
Varroa derived virus 1 (VaDV-1) & 10 \\
Sacbrood virus (SBV) & 4 \\
Chronic bee paralysis virus (CBPV) & $<1$ \\
Acute bee paralysis virus (ABPV) & $<1$ \\
\hline
\end{tabular}

* The total sum is above $100 \%$ since many hives are infested with more than one virus.

not statistically significant (tau- $\mathrm{b}=-0.19, \mathrm{n}=$ $68, P=0.06)$. In a multiple linear regression model using the presence of Nosema, Varroa, and detected viruses to predict the population of adult bees, the only significant variable was the presence of BQCV $\left(\mathrm{t}_{58}=-2.84\right.$, $P<0.01$ ), with a negative effect on bee population.

\section{DISCUSSION}

The extent of colony losses across Israel is difficult to asses. By surveying beekeepers, we were able to estimate the levels of losses and the most common observed symptoms that could be associated with some of them. The causes for most of the losses were unknown and could be attributed to multiple factors like pests, diseases, or pesticides. An elevated incidence of high losses was more common in rather small beekeeping operations (less than 100 hives). The reason for this finding is unknown, although it is possible that a single factor could affect all colonies if they were in one or a few close apiaries and have less of an effect on larger operations. Also, professional management might have played a significant role in prevention of losses, since the lowest losses were reported by growers implementing prophylactic treatments against Nosema and Varroa. Higher losses in small operations were also observed in Poland (Topolska et al., 2008) but not in the US (van Engelsdorp et al., 2008). In the latter study, the main symptom of CCD (lack of dead bees in collapsed colonies) was more common to beekeepers with larger operation sizes. In such operations, bees are exposed not only to various stressors (such as movement, pesticides, and nutritional deficiencies) but also to high colony density that facilitates distribution of pests and pathogens among colonies. In Israel, the overall density of the hives is very high (above 14 colonies per sq $\mathrm{km}$ ). Thus the density factors are expected to affect similarly large and small operations. Systematic examination of 113 selected hives at 12 sites through the country revealed a CCD-like syndrome in one hive only. However, by July, a total of 9 hives collapsed.

Usually, when provided with sugar solution, overwintering does not present survival difficulties for local colonies. The winter in Israel is mild and colonies maintain brood throughout this period. During the winter of 2008-2009, the air temperatures were relatively high with very low precipitation, thus limited foraging sources for the bees were available. Yet colony population was, overall, normal and bees with disease symptoms (sacbrood, paralysis or deformed wings) were rarely observed $(9 \%)$. However, PCR examination revealed that $73 \%$ of the tested hives displayed asymptomatic virus infections (BQCV, IAPV, DWV, VaDV-1, SBV, ABPV). $\mathrm{KBV}$ and CBPV were not detected. However, we should note that the presence of CBPV in the hives could be underestimated, since it was monitored using the pair of primers published by Blanchard et al. (2007), and it is conceivable that a higher rate of incidence of this virus could be obtained utilizing the pair of primers described later (Blanchard et al., 2008).

In $42 \%$ of them, more than one virus was detected in the same sample. Some colonies 


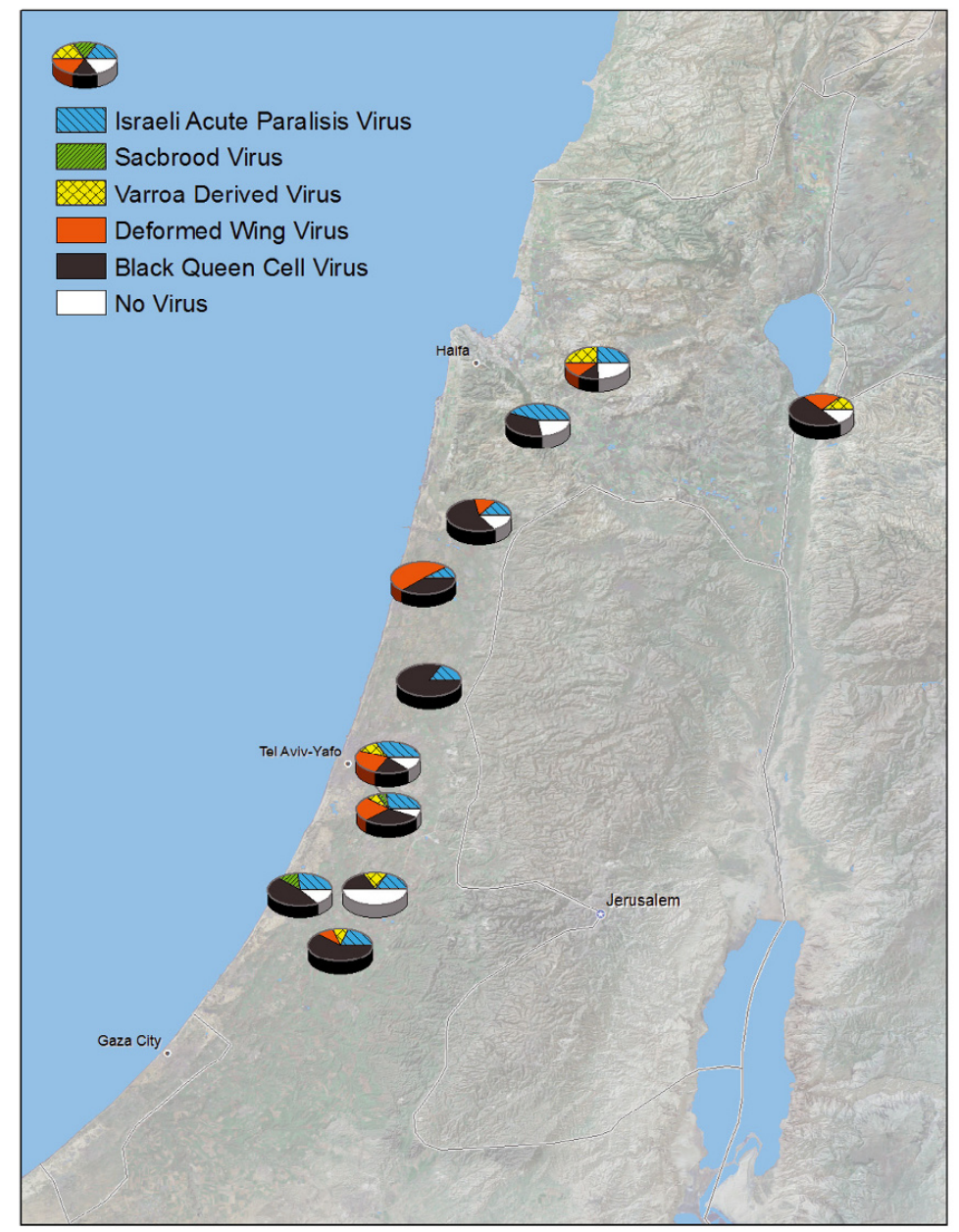

Figure 4. Distribution of viral infection at monitored sites. Relative frequency of viruses infected (colored) and uninfected (white) hives at each spot.

were infested with Nosema or Varroa as well. Only $5 \%$ of the hives in the survey were diagnosed as free of pathogens. A significant negative correlation between viral infections and the size of the worker population was observed, despite the fact that most of these infections lacked clinical signs, which suggests that there might be a cost to viral infection.

Regardless of the known role of $V$. destructor on colony health and viral transmission (Yang and Cox-Foster, 2005; Gregory et al., 2005; Chen and Siede, 2007; Navajas et al., 2008), we found neither a negative correlation between the presence of Varroa and the size of the colony population, nor a positive correlation between the incidence of different viruses and Varroa. This is probably the result of low levels of Varroa, which was less than one mite per colony, due to its intensive control with Checkmite $+{ }^{\circledR}$ applications twice a year. Under these low infestation levels, the positive correlation between Varroa and capped-brood area is not surprising, since Varroa reproduction is brood dependent.

The fact that Nosema was detected in about third of the tested hives using microscopic 
protocols-despite the routine treatment with the antibiotic fumagilin-should raise concern in light of recent reports that this pathogen might cause colony losses and collapse (Topolska et al., 2008; Higes et al., 2008, 2009). N. ceranae appears to be more resistant than $N$. apis to high temperatures and follows different seasonality. Thus, accordingly, its management may require modification of the measures adopted for treatment of $N$. apis infestations (Oliver, 2009).

In summary, we found that a high proportion of apparently healthy colonies bore multiple pathogens. We are conducting follow up studies of these colonies and their respective apiaries to gain deeper insights into the significance of these findings to colony survival.

\section{ACKNOWLEDGEMENTS}

We would like to thank Saadia Reneh and Ilia Zaidman for technical assistance. The research was partially financed by the Chief Scientist of the Israeli Ministry of Agriculture, the Israeli Honey Board, and the Plant Growers Association project \# 131-1510-0. We thank two anonymous reviewers for their fruitful comments.

Évaluation des pertes de colonies en Israël en relation avec le rôle des maladies et ennemis des abeilles.

\section{Apis mellifera / virus / Varroa / Nosema / Israël / surveillance phytosanitaire}

\footnotetext{
Zusammenfassung - Die Beurteilung von Völkerverlusten in Israel im Zusammenhang mit dem Auftreten von Bienenkrankheiten und Parasiten. Israel weist im weltweiten Vergleich eine extrem hohe Dichte an Bienenvölkern auf, da sich die Imkerei auf die wenigen nicht ariden Gebiete des Landes konzentriert. In letzter Zeit klagen Berufsimker über Abnahmen von Volksstärke und Honigertrag. Zudem wird vermutet, dass der jährliche Verlust an Bienenvölkern mit $25 \%$ sehr hoch ist. Es wurde daher eine umfangreiche Untersuchung eingeleitet, um (1) den Umfang und die Symptome der Völkerverluste zu erfassen und (2) die Bedeutung von Krankheiten und Parasiten für die Gesundheit der Bienenvölker zu ermitteln. In dieser Untersuchung werden die Umfrageergebnisse nach dem Winter 2009 bei 100 registrierten Erzeugern vorgestellt; diese Großbetriebe repräsentieren zwar nur
}

$13 \%$ der Imker, halten aber über $50 \%$ der Bienenvölker des Landes. Bei 113 Völkern an 12 ausgesuchten Bienenständen wurden zusätzlich folgende systematische Untersuchungen durchgeführt: (1) Abschätzen der Bienen- und Brutpopulation; (2) Erfassung des Gesundheitszustandes von Bienen und Brut; (3) Abschätzen der Varroapopulation durch Auszählen von Bodeneinlagen eine Stunde nach Begasen mit Amitraz, und (4) Sammeln von Adultbienen für Krankheitsuntersuchungen. Dabei wurde ein Screening nach Nosema ceranae, N. apis und Bienenviren (ABPV, BQCV, CBPV, IAPV, KBV, $\mathrm{SBV}, \mathrm{VaDV}-1$ = Varroa destructor -Virus 1) über RT-PCR mit spezifischen Primern durchgeführt.

Es beteiligten sich 85 Imker mit insgesamt 46000 Bienenvölkern an der Umfrage. Die Verlustraten schwankten erheblich und lagen bei den meisten Imkern unter $20 \%$; Verluste über $40 \%$ traten vor allem bei kleineren Betrieben mit bis zu 100 Völkern auf. Die Ursachen für die Verluste waren zumeist unbekannt und es wurde vermutet, dass hierbei mehrere Faktoren zusammenspielen. Von den 113 speziell untersuchten Bienenvölkern wurden bei $35 \%$ mikroskopisch Nosemabefall festgestellt. Dieser wurde in $77 \%$ der Fälle durch PCR bestätigt, wobei ausschließlich $N$. ceranae nachgewiesen wurde. Zwischen dem $N$. ceranae-Befall und der Bienenpopulation wurde eine signifikante negative Korrelation nachgewiesen. V. destructor wurde in $21 \%$ der Völker nachgewiesen. Trotz des hohen Prozentsatzes von Völkern mit Varroa destructor war die Anzahl der Milben pro Volk sehr gering und hatte keinerlei negativen Effekt auf die Bienenpopulation. Ein Mehrfachbefall mit Bienenviren wurde an allen untersuchten Standorten nachgewiesen. $82 \%$ der Bienenvölker wurden Virus positiv getestet, davon $42 \%$ mit mehr als einem Bienenvirus. BQCV, IAPV, DWV, und VaDV-1 kamen am häufigsten vor, CBPV und KBV wurden dagegen nicht nachgewiesen. In $73 \%$ der Fälle waren die Virusinfektionen symptomlos. Nur $5 \%$ der Bienenvölker waren frei von nachweisbaren Krankheitserregern. Obwohl es keine eindeutigen klinischen Symptome für Virusinfektionen gab, wurde eine signifikante negative Korrelation zwischen der Population an Adultbienen und dem Vorkommen von Virusinfektionen, insbesondere BQCV, festgestellt. Dies weist darauf hin, dass auch symptomlose virale Infektionen „Kosten“ für das Bienenvolk verursachen.

\section{Apis mellifera / Bienenviren / Varroa / Nosema}

\section{REFERENCES}

Benjeddou M., Leat N., Allsopp M., Davison S. (2001) Detection of acute bee paralysis virus and black queen cell virus from honeybees by reverse transcriptase PCR, Appl. Environ. Microbiol. 67, 2384-2387. 
Berényi O., Bakonyi T., Derakhshifar I., Köglberger H., Nowotny N. (2006) Occurrence of six honeybee viruses in diseased Austrian apiaries, Appl. Environ. Microbiol. 72, 2414-2420.

Blanchard P., Olivier V., Iscache A.L., Celle O., Schurr F., Lallemand P., Ribière M. (2008) Improvement of RT-PCR detection of chronic bee paralysis virus (CBPV) required by the description of genomic variability in French CBPV isolates, J. Invertebr. Pathol. 97, 182-185.

Blanchard P., Ribière M., Celle O., Lallemand P., Schurr F., Olivier V., Iscache A.L., Faucon J.P. (2007) Evaluation of a real-time two-step RT-PCR assay for quantitation of Chronic bee paralysis virus (CBPV) genome in experimentally-infected bee tissues and in life, Appl. Environ. Microbiol. 73, 7711-7716.

Chen Y., Pettis J.S., Feldlaufer M.F. (2005) Detection of multiple viruses in queens of the honey bee Apis mellifera L., J. Invertebr. Pathol. 90, 118-121.

Chen Y.P., Siede R. (2007) Honey bee viruses, Adv. Virus Res. 70, 33-80.

COLOSS: http://coloss.org/.

Cox-Foster D.L., Conlan S., Holmes E.C., Palacios G., Evans J.D., Moran N.A., Quan P.L., Briese T., Hornig M., Geiser D.M., Martinson V., vanEngelsdorp D., Kalkstein A.L., Drysdale A., Hui J., Zhai J., Cui L., Hutchison S.K., Simons J.F., Egholm M., Pettis J.S., Lipkin W.I. (2007), A metagenomic survey of microbes in honey bee colony collapse disorder, Science 318, 283-287.

Guzmán-Novoa E., Eccles L., Calvete Y., Mcgowan J., Kelly P.G., Correa - Benítez A. (2010) Varroa destructor is the main culprit for the death and reduced populations of over wintered honey bee (Apis mellifera) colonies in Ontario, Canada, Apidologie, in press, DOI: 10.1051/apido/2009076.

Efrat H., Slabezki (2007) Bees' hidden death, Colony Collapse disorder (CCD), Yalkut Hamichveret (in Hebrew) 47, 22-24.

EFSA (European Food Safety Agency) (2008) A report by the Assessment Methodology Unit in response to Agence de Securite Sanitaire des Aliments (AFSSA): Bee Mortality and bee surveillance in Europe, The EFSA J. 154, 1-28.

Giray T., Kence M., Oskay D., Ali Döke M., Kence A. (2010) Scientific note: colony losses survey in Turkey and causes of bee deaths, Apidologie (in press), DOI: 10.1051/apido/2009077.

Gregory P.G., Evans J.D., Rinderer T., de Guzman L. (2005) Conditional immune-gene suppression of honeybees parasitized by Varroa mites, J. Insect Sci. 5, 7 .

Herbert E.W., Witherell P.C., Bruce W.A., Shirnanuki H. (1989) Evaluation of six methods of detecting Varroa mites in beehives, including the experimental use of acaricidal smokes containing flu- valinate or arnitraz, Am. Bee J. 129, 605-608.

Higes M., Martin-Hernández R., Botias C., Garrido Bailon E., Gonzalez-Porto A.V., Barrios L., Nozal M.J.D., Bernal J.L., Jimenez J.J., Garcia Palencia P., Meana A. (2008) How natural infestation by Nosema ceranae causes honeybee colony collapse, Environ. Microbiol. 10, 2659-2669.

Higes M., Martin-Hernández R., Garrido-Bailón E., González-Porto A.V., García-Palencia P., Meana A., del Nasal M.J., Mayo R., Bernal J.L. (2009) Honeybee colony collapse due to Nosema ceranae in profesional apiaries, Environ. Microbiol. R. 1, 110-113.

Maori E., Tanne E., Sela I. (2007) Reciprocal sequence exchange between non-retro viruses and hosts leading to the appearance of new host phenotypes, Virology 362, 342-349.

Martin-Hernández R., Meana A., Prieto L., Martinez Salvador A., Garrido-Bailón E., Higes M. (2007) Outcome of colonization of Apis mellifera by Nosema ceranae, Appl. Environ. Microbiol. 73, 6331-6338.

Navajas M., Migeon A., Alaux C., Martin-Magniette M., Robinson G., Evans J., Cros-Arteil S., Crauser D., Le Conte Y. (2008) Differential gene expression of the honey bee Apis mellifera associated with Varroa destructor infection, BMC Genomics 9, 301

Oliver R. (2009) N. ceranae: kiss of death or much ado about nothing, Am. Bee J. 149, 759-764.

Ongus J.R., Peters D., Bonmatin J.M., Bengsch E., Vlak J.M., van Oers M.M. (2004) Complete sequence of a picorna-like virus of the genus Iflavirus replicating in the mite Varroa destructor, J. Gen. Virol. 85, 3747-3755.

Stolz D., Shen X.-R., Boggis C., Sisson G. (1995) Molecular diagnosis of Kashmir bee virus infection, J. Apic. Res. 34, 153-160.

Topolska G., Gajda A., Hartwig A. (2008) Polish honey bee colony-loss during the winter of 20072008, J. Apic. Sci. 52, 95-104.

van Engelsdorp D., Hayes Jr. J., Underwood R.M., Pettis J. (2008) A survey of Honey Bee Colony losses in the US, Fall 2007 to spring 2008, Plos One 3, e4071, 1-6. www.plosone.org.

van Engelsdorp D., Evans J.D., Saegerman C., Mullin C., Haubruge E., Nguyen B.K., Frazier M., Frazier J. , Cox-Foster D., Chen Y., Underwood R.M., Tarpy D.R., Pettis J. (2009) colony collapse disorder: a descriptive study, Plos One 4, e6481, 1-16. www.plosone.org.

Yang X., Cox-Foster D.L. (2005) Impact of an ectoparasite on the immunity and pathology of an invertebrate: evidence for host immunosuppression and viral amplification, Proc. Natl. Acad. Sci. USA 102, 7470-7475. 